\title{
The Path of European Institutional and Economic Integration: What Lessons for Latin America?
}

\author{
Ettore Dorrucci \\ $E C B$ \\ Stefano Firpo \\ San Paolo-IMI \\ Marcel Fratzscher and Francesco Paolo Mongelli \\ $E C B$
}

\begin{abstract}
What lessons can be drawn from the European experience with regional integration that started in the 1950s, for regional integration in Latin America, which is still in its early stages? We present here a new indicator of institutional integration and study how it developed vis-à-vis diverse measures of economic integration. We find that Latin America is currently less economically integrated not only than the European Union today, but in some cases even than the EU at the beginning of its regional integration process. A cluster analysis illustrates that the link between institutional and economic integration has worked both ways throughout the European experience. The more institutional integration went beyond the creation of a customs union and moved towards a common market and an economic and monetary union, the deeper economic integration turned out. Increasing economic integration in turn corroborated and sustained the process of
\end{abstract}

\footnotetext{
*Corresponding address: Francesco Paolo Mongelli, European Central Bank, Kaiserstrasse 29, D-60311 Frankfurt am Main, Germany, E-mail: Francesco.Mongelli@ecb.int

@2005-Center for International Economics, Sejong Institution, All Rights Reserved.
} 
institutional integration.

- JEL Classifications: E42, F15, F33, F4

- Key words: Regional integration in Europe and Latin America, intra-regional exchange rate variability, optimum currency area

\section{Introduction}

Latin American countries are currently confronted with two main options concerning their prospects for regional integration. The first option relates to the choice of partners. Costs and benefits of so-called "South-South" arrangements i.e., intra-regional arrangements such as the Common Market of the South (Mercosur) - need to be compared with those of "North-South" arrangements - i.e., inter-regional arrangements such as the Free Trade Area of the Americas (FTAA). The second option, with which this article is mostly concerned, regards the depth of integration: the desirability of free trade arrangements has to be weighed vis-àvis deeper forms of integration, which are likely to be more costly and lengthy to undertake.

European countries have confronted similar choices in the past, and the European path of integration, that started in the 1950s, shows that both options i.e., the choice of partner and the depth of integration, are not mutually exclusive. In fact, they complement each other over time (as argued, for instance, in World Bank (2000) and Scandizzo (2002)). We ask here what broad lessons there might be from European integration for other regions in the world. For this purpose we develop a new set of indicators of institutional and economic integration.

Institutional integration is defined here as the outcome of joint policy decisions designed to affect the depth and breadth of regional integration over time. Our new measure of institutional integration is based on the classification of regional integration developed by Balassa (1961). Economic integration is captured by several measures of real, financial and monetary integration in a given region. In particular, we look at a number of variables suggested by the optimum currency area (OCA) theory. These include measures of the synchronisation of the business cycle, convergence of inflation rates, exchange rate variability, trade openness and integration, convergence of interest rates, and income convergence. A cluster analysis allows us to tackle a series of inter-related questions. How integrated are the economies within Europe and within Latin America? Can one identify homogenous 
groups of countries within regions? And if so, what makes countries within groups similar? How did real and nominal economic integration proceed over time? What is the interaction between institutional and economic integration?

To our knowledge, the approach pursued in this paper is rather novel. ${ }^{1}$ It might provide some useful insight in addition to the work of other authors that have investigated specific aspects of regional integration and economic policies in Latin America. ${ }^{2}$ For instance, Calvo and Mendoza (1997) and Milesi-Ferretti and Razin (1997) have examined the sustainability of current accounts imbalances and fiscal policies. Other authors have focussed on the choice of exchange rate arrangements and the timing of monetary union in Latin America: see for example Eichengreen (1998), Berg, Borensztein and Mauro (2000), and Fratianni and Hauskrecht (2002). Alberola, Busián and Fernández de Lis (2002) discuss the links between economic integration, macroeconomic stability and structural reforms. García Herrero and Santillán (2002) compare the degree of financial sector development across Latin American countries. Finally, Hochreiter, Schmidt-Hebbel and Winkler (2002) assess the issue of the sustainability of a monetary union in Latin America vis-à-vis the European experience.

The paper is organised as follows. Section 2 presents the index of institutional regional integration describing the main stages of institutional co-operation among groups of European and Latin American countries, each taken as a whole. Section 3 presents some selected indicators of economic integration, including some measures of exchange rate variability in the two regions. Section 4 conducts a cluster analysis addressing the questions spelled out above. Section 5 presents some concluding remarks.

\section{An Institutional Index of Regional Co-operation for the European Union and Mercosur}

We trace here the main stages of institutional regional co-operation by constructing an index for the EU and Mercosur. After explaining our methodology,

\footnotetext{
${ }^{1}$ Two papers pursuing a similar approach should be mentioned. The first is Ben-David (1993) that however only focuses on the link between the timing of trade reform and income convergence among countries. The second paper is Dorrucci, Firpo, Fratzscher and Mongelli (2004) that uses the novel indicators of institutional and economic integration developed herein to investigate a more systematic link between these indicators by employing a VAR analysis.

${ }^{2}$ Ben-David (1993) uses quite a similar approach, but he only focuses on the link between the timing of trade reform and income convergence among countries.
} 
we review the main indications that can be drawn from the progression of this index within the EU and Mercosur over time.

\section{A. Methodology}

Institutional regional co-operation (IRC) can be defined as the outcome of policy decisions taken by regional intergovernmental fora and/or supranational institutions in order to affect the:

- depth of regional integration, i.e. its objectives in terms of economic integration;

- breadth of regional integration, i.e. its membership.

In the following we present a general methodology, based on Dorrucci et alii (2002), to measure the depth of IRC.

According to this methodology, the policy decisions affecting the depth of regional integration are considered per se, i.e. without analysing their actual impact on the degree of economic integration as measured by the variables analysed in Section 3 . Our methodology builds on the seminal contribution of Balassa, which, as illustrated in Table 1, identified five main "stages" of regional integration" (Balassa 1961).

Table 1. The five "Balassa stages" of regional integration

\begin{tabular}{|c|c|}
\hline $\begin{array}{l}\text { The five stages of regional } \\
\text { integration }\end{array}$ & Definition \\
\hline 1. Free Trade Area & $\begin{array}{l}\text { An area where tariffs and quotas are abolished for imports } \\
\text { from area members, which, however, retain national tariffs } \\
\text { and quotas against third countries }\end{array}$ \\
\hline 2. Customs Union (CU) & $\begin{array}{l}\text { A FTA setting up common tariffs and quotas (if any) for trade } \\
\text { with non-members }\end{array}$ \\
\hline 3. Common Market & $\begin{array}{l}\text { A CU abolishing non-tariff barriers to trade (product and ser- } \\
\text { vices markets integration) as well as restrictions on factor } \\
\text { movement (factor market integration) }\end{array}$ \\
\hline 4. Economic Union & $\begin{array}{l}\text { A CM with a significant degree of co-ordination of national } \\
\text { economic policies and/or harmonisation of relevant domestic } \\
\text { laws }\end{array}$ \\
\hline $\begin{array}{l}\text { 5. Total Economic Integratio } \\
\text { (TEI) }\end{array}$ & $\begin{array}{l}\text { An EUN with all relevant economic policies conducted at the } \\
\text { supranational level, possibly in compliance with the principle } \\
\text { of subsidiarity. To this aim, both supranational authorities and } \\
\text { supranational laws need to be in place }\end{array}$ \\
\hline
\end{tabular}

Source: Balassa (1961), as brought up to date by the authors.

\footnotetext{
${ }^{3} \mathrm{~A}$ possible final step, which goes beyond the five stages identified in the Balassas contribution and is not discussed in this paper, is Political Union.
} 
An important qualification, which differentiates our methodology from the Balassa approach, is that the above "stages" are not necessarily considered as steps to be followed within a "right sequencing" framework. The favoured countries attitude is in fact that of a "menu approach" whereby countries are at liberty to choose a particular form of IRC, and participation in one scheme is not necessarily a pre-requisite for participation in another. This implies that the "Balassa stages" tend to a significant extent to develop in parallel, which means that the term "stage" is indeed somewhat misleading. Experience shows that this not only applies to Latin American and, to an even greater extent, East Asian arrangements, but also to the EU experience. For instance, when it became a customs union (1968), the European Economic Community had already one fundamental characteristic of TEI, i.e. a number of supranational institutions and the structuring of integration through Community law. We therefore measure depth in parallel for each of the five "stages", which, for the sake of consistency, will be thereafter called "components" of regional integration. ${ }^{4}$

For the purposes of this paper, the overall degree of institutional integration achieved within a regional arrangement at a given point in time can be quantified by assigning numbers ("scores") to the level of integration recorded, for each of these five components, throughout the relevant period (e.g. 1991-2002 for Mercosur). This allows us to measure, and therefore compare, the various regional arrangements in a relatively homogeneous way, although with some unavoidable degree of discretion and judgement, which should be taken into account as a caveat.

We assign scores from 0 to 25 to the degree of regional integration achieved over time in the development of, respectively, a Free Trade Area/Customs Union (FTA/ $\mathrm{CU}$, considered jointly), a Common Market (CM), an Economic Union (EUN), and an area with Total Economic Integration (TEI). By summing up the scores achieved in each moment in time (we use monthly data), an index of institutional regional integration (IRC index) is obtained which can range between 0 (no economic integration at all) and 100 (full economic integration, including e.g. monetary and economic union). To the extent possible, scores are not assigned on the basis of the year when a certain decision was taken (e.g. Treaty of Rome in 1957), but rather the year and month when such a decision started being actually implemented (e.g. lowering of EU-6 internal tariffs between 1959 and 1968). This implies that those projects which were never implemented (e.g. Werner Plan) are not taken into account.

\footnotetext{
${ }^{4}$ The approach chosen does not mean that the issue of right sequencing is irrelevant. This section, however, aims to only measure IRC without taking a position on its features.
} 
The institutional index of regional integration is here constructed for:

- EU (Belgium, Germany, France, Italy, Luxembourg, the Netherlands (EU-6), Austria, Denmark, Finland, Greece, Ireland, Portugal, Spain, Sweden, United Kingdom);

- Mercosur (Brazil, Argentina, Paraguay, Uruguay).

We first apply our methodology to (i) the core group of countries that started the process of IRC (i.e. EU-6, while for Mercosur the core group coincides with the whole group), considered as a whole ("composite IRC index"), and then to (ii) each individual member country including those that subsequently joined the arrangement, thus affecting its breadth.

The reason why we prefer using the composite IRC index only for the core group of member countries (EU-6) instead of the current member countries (e.g. EU-25) is that the path followed by each individual country in joining the regional arrangement has been quite heterogeneous over time.

In the case of the EU one should in fact distinguish among these country groupings or individual countries:

a. EU-6 (i.e., BE, DE, FR, IT, LU, NL),

b. Ireland (IE), which joined the EU in 1973,

c. Denmark and United Kingdom (DK, UK), which also joined the EU in 1973,

d. Greece (GR), which joined the EU in 1981,

e. Spain and Portugal (ES, PT), which joined the EU in 1986,

f. Austria and Finland (AU, FI), which joined the EU in 1995,

g. Sweden (SE), which also joined the EU in 1995,

h. the new member states that joined the EU in 2004.

Each of these groupings or individual countries proceeded with its own speed and path in the process of integration with other partner countries. ${ }^{5}$ This implies that a composite IRC index for the EU-25, though feasible, would be more arbitrary and difficult to interpret than for EU-6.

\footnotetext{
${ }^{5}$ EU-6 countries followed a relatively homogeneous path. As regards the 19 remaining EU Member States, IE had implemented all measures to participate in the CU already by 1977 , and became a member of the euro area in 1999. DK and UK also entered the customs union in 1977, but do not participate in EMU. DK, however, participates in the ERM II, which is not the case of UK. GR accomplished the transition to the CU in 1986, and adopted the euro in 2001. ES and PT became EU members in 1986, entered the CU only in 1995, and EMU in 1999. AU and FI became members of both the EU and the CU in the same year (1995), and adopted the euro in 1999. Finally, this paper does not consider the ten remaining EU member as they joined the Union too resently.SE differs from AU and FI as it is does not participate in EMU, but differently from DK and UK does not have an "opting-out" clause.
} 
In Box 1 the general criteria and indicators used to assign scores to each of the "Balassa components" are illustrated. We decided to give a particular emphasis to those policies that are likely to indirectly or directly affect the need for intraregional exchange rate stability.

In addition, for each of the considered arrangements, Dorrucci et alii (2002) also (i) report the specific scores given to individual events in the process of IRC and (ii) summarise the analysis in a table providing an historical perspective (see Appendix 1). The advantage of presenting this methodology "step-by-step" is that this allows the reader to alter the IRC index should s/he wish to change any of the

\author{
Box 1 General criteria and indicators used to construct the institutional index of regional integration \\ N.B.: The specific scores assigned, for each of the indicators below, to the EU-6 and Mercosur over time, are \\ presented in Dorrucci et alii (2002), Appendix 1. \\ Indicators Used For a Free Trade Area (FTA) And a Customs Union (CU)
}

(1) Changes over time of tariffs and quotas on trade within the area (FTA) and vis-à-vis third countries $(\mathrm{CU})^{6}$ - This is by far the most important indicator for a FTA/CU, which also presents the advantage of being easily measurable and unbiased.

Using these scores, a fully-fledged CU (i.e., incorporating a FTA) would obtain a score of 25 (which is e.g. the case for EU-6), while the intermediate stages may obtain from 1 to 13 points. The final step toward a FTA/ CU therefore obtains a much higher weight than each intermediate step. The same "non-linear" approach applies also to the other Balassa stages described hereafter.

Indicators Used for Common Market (CM)

(2) Progress in abolishing non-tariff barriers - The creation of a CU does not automatically imply full integration of product and services markets within a region. A further step is needed to this aim, namely the abolition of all measures with an effect comparable to that of tariffs and quotas. In the EU case, for example, in 1974 the European Court of Justice defined such measures as "all trading rules enacted by Member States which are capable of hindering, directly or indirectly, actually or potentially, intra-Community trade" ("Dassonville" case 8/74).

(3) Measures taken in order to liberalise the movement of capital ${ }^{7}$ - In this regard, it could be observed that the role which measures on capital movement play in a process of regional integration is twofold. On the one hand, restrictions on capital movements may be interpreted as a key precondition to preserve some degree of intraregional exchange rate stability coupled with some degree of monetary policy autonomy. On the other hand, the liberalisation of capital movements leads to a monetary union if member countries want to preserve intra-regional exchange rate stability. Although this "impossible trinity" approach is correct, taken alone it does not sufficiently emphasise another key proposition, namely that the decisive and ultimate precondition for intra-regional exchange rate stability is intra-regional economic convergence. This means that capital flow restrictions can well play a role in preserving exchange rate stability for some time, but in the longer run they can jeopardise this objective. The reason is that they allow policy makers to postpone the implementation of those measures which eventually result in both convergence and greater exchange rate stability. As the European experience of the early 1990s clearly illustrates, free capital movement is a key factor driving economic convergence. Consequently, in our methodology all steps towards the liberalisation of capital movements obtain a positive score, whereas all restrictive measures receive a negative one. Emphasis is given to those measures which were taken at the regional level, since liberalisation in one individual country does not per se imply increased integration.

${ }^{6}$ In the EU-6 case the start of the Common Agricultural Policy (CAP) in 1962 is also considered. The CAP is here taken into account only as a precondition without which it would not have been possible to extend the FTA to agricultural goods. For this reason, the start of the CAP in 1962 implies one additional point. The implications of CAP as an EU common policy are instead considered when analysing the steps towards TEU. 
(4) Measures taken to liberalise the movement of workers - This is another key indicator, in line with Mundells seminal paper (Mundell 1961). However, achieving a single labour market is far more demanding than integrating product, services and financial markets.

On the whole, a $\mathrm{CM}$ as such (i.e, without considering the other stages of regional integration) would obtain 25 points. Indicators Used for an Economic Union (EUN)

(5) The degree of co-ordination of national macroeconomic policies (i.e., fiscal, exchange rate and monetary policies) - How to incorporate regional macroeconomic policies in the index of regional integration is a complex issue, open to discussion. Such policies, in fact, cannot be considered as independent of the need for regional exchange rate stability, but they are largely endogenous. For instance, in Europe the establishment of the European Monetary System (EMS) in 1979 was clearly intertwined with the need for exchange rate stability in the region. Thus, it is impossible to find a direction of causality between regional integration and the need for intra-regional exchange rate stability (as it might still be the case, for instance, for the establishment of the $\mathrm{CU}$ or the $\mathrm{CM}$ ).

Two avenues can be followed to tackle this problem.

The first avenue is that followed in this paper. According to this approach, the degree of co-ordination of all regional macroeconomic policies should become an integral part of the index. The rationale for this approach is that not only in the case of macroeconomic policies, but also more generally it is impossible to disentangle the direction of causality between a process of regional integration and the need for exchange rate stability as illustrated by the OCA variables.

Along an alternative avenue, macroeconomic policies should not be taken into account, in order to circumvent the problem of circular causation. This avenue is not followed in this paper.

(6) The implementation, at the regional level alongside the national level, of those microeconomic policies which are most likely to affect the need for regional exchange rate stability - The latter policies are mainly: (b.l) competition policy (i.e., measures designed to forbid subsidies and regulations that favour domestic producers); (b.2) transport policy; (b.3) harmonisation of VAT on trade of goods and services; and b.4) harmonisation of other national structural (in particular, labour market) policies in order to increase price (in particular, labour cost) flexibility within the region. The successful implementation of these four policies is likely to increase the cross-border price elasticity of demand for similar products produced in different countries participating in the regional arrangement. The higher the elasticity, the more strongly a swing in the exchange rate can shift sectoral competitive advantages within the area, thus affecting profitability and possibly triggering political reactions. Conversely, the link between the need for regional exchange rate stability and other microeconomic policies (e.g. R\&D policy and environmental policy) seems uncertain and in any case more indirect. The latter policies are therefore not taken into account.

On the whole, an EUN as such (i.e, without considering the other stages of regional integration) would obtain 25 points.

Indicators Used For Total Economic Integration (TEI)

(7) The set-up of supranational institutions and decision-making processes, as well as the structuring of the process of regional integration through laws issued and enforced at the supranational level - Of course, the use of this indicator only with regard to TEI is somewhat arbitrary. Supranational institutions and laws can indeed play a crucial role also when building up, for instance, a FTA or a CM. It is equally true, however, that, when pursuing total economic integration, supranational institutions and laws become not only a desirable but also a necessary condition.

(8) The concrete steps towards, and the conduction of, macroeconomic and microeconomic policies at the supranational level - The most relevant example is EMU.

${ }^{7}$ In this paper technology is not considered as a separate factor. This is based on the assumption that capital movements include FDI, which is a major instrument of technology transfer. Opening a branch, setting up joint ventures, and acquiring foreign companies in order to horizontally or vertically extend the production structure, is a significant component of capital movement. However, it should be borne in mind that, according to certain empirical studies, FDI fails to transfer technology since technology improvements often remain confined to the headquarters. If this were true, it would imply that technology should be measured as a separate factor. 
hypotheses or judgements.

\section{B. What does the institutional index of regional integration tell us regarding the EU?}

Figure 1 outlines the evolution of the composite index of institutional regional integration for EU-6 from 1957 to 2001. Two main features of the European process of integration emerge. First, the EU/euro area ${ }^{8}$ obtains a score as high as 86 out of 100 at the end of 2001 (see Figure 1.1). The EU/euro area can indeed claim, at the same time, a developed common market, strong policy co-ordination, a single monetary and exchange rate policy, and, what can be seen as a major requirement for the aforementioned achievements, supranational institutions and supranational laws enforced by the courts. If one used the EU as a yardstick to measure regional integration processes around the world, it would be expected that the other existing arrangements obtain a much lower score (see next sub-section as far as Mercosur is concerned). Nevertheless, even using, as we do, a model of integration both based on the principle of subsidiarity and not considering the ultimate stage of Political Union, the EU does not obtain the highest score possible. Further steps in the deepening of European regional integration can be envisaged especially in the areas of labour

Figure 1. Institutional index of integration for EU-6 countries.

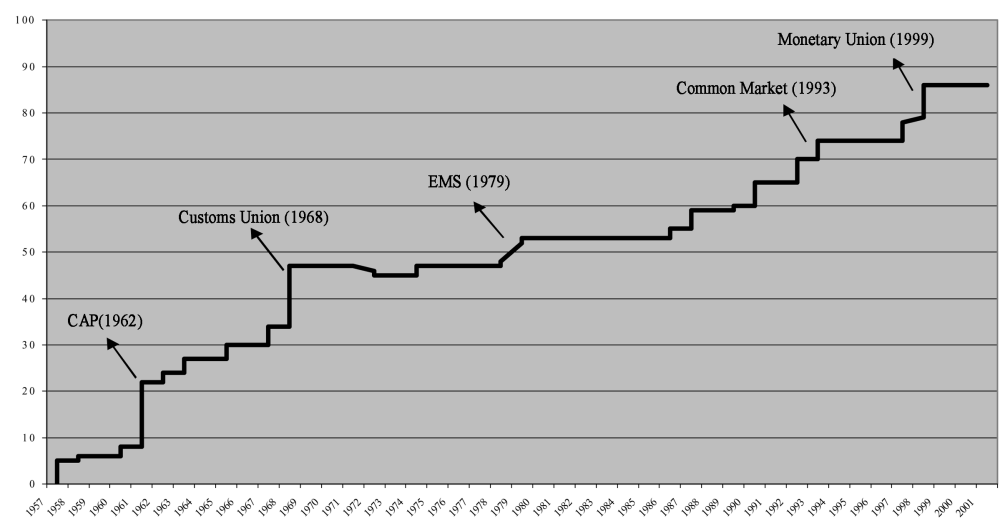

Notes: EU-6 is here taken as a whole $(1957=0$, highest score possible for regional integration: 100). EU-6 countries are Belgium, France, Germany, Italy, Luxembourg and the Netherlands

Source: Author's own calculations based on various sources and in line with the methodology described in Section 2.1.

\footnotetext{
${ }^{8}$ It should be noted that, since the adoption of the euro in 1999 (2001 for Greece), all 12 euro area Member States have reached the same level and follow the same path of institutional integration. This implies that since 1999 the groupings "EU-6" and "euro area" are equivalent in terms of score in Figure 1.1.
} 
mobility, harmonisation of national structural policies (e.g. in the area of labour market flexibility), further deepening of integration in European capital markets, and co-ordination of those macroeconomic policies which are not unified.

Second, EU-6 countries (Figures 2) have exhibited the greatest progress in integration and set the upper bound against which other EU members have followed their own path of regional integration. By 2001 six other EU countries

Figure 2. Institutional Index of integration for Belgium, France, Germany, Luxembourg, Italy and the Netherlands taken individually (1957- 2001).

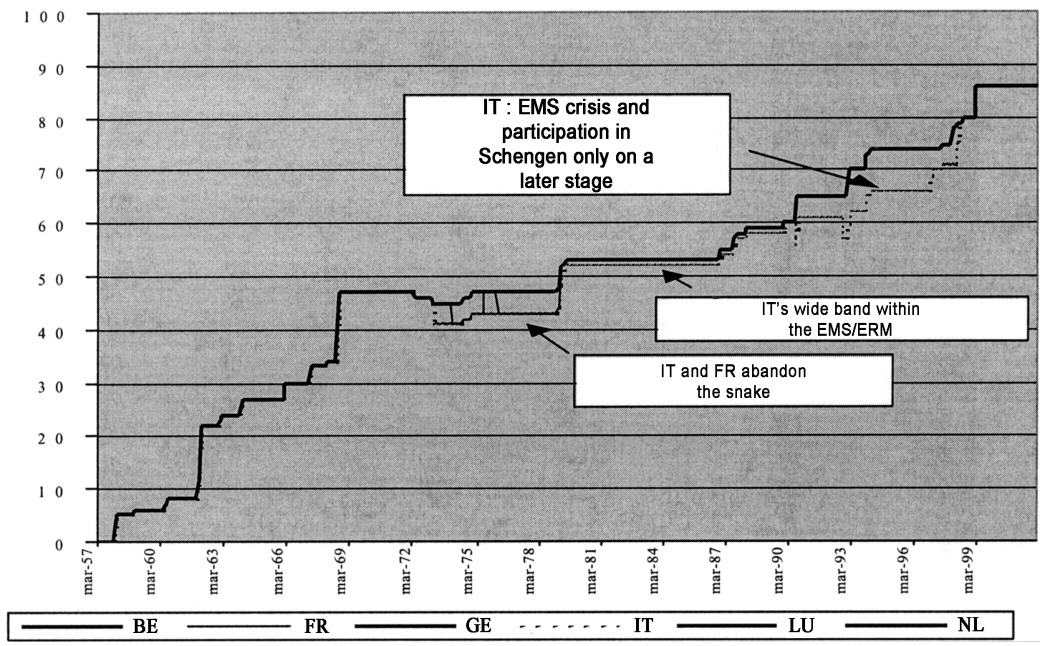

Source: Authors own calculations based on various sources and in line with methodology described in Section 2.1 .

Figure 3. Institutional index of integration for Austria, Finland, Greece, Ireland, Portugal and Spain taken individually (1957-2001).

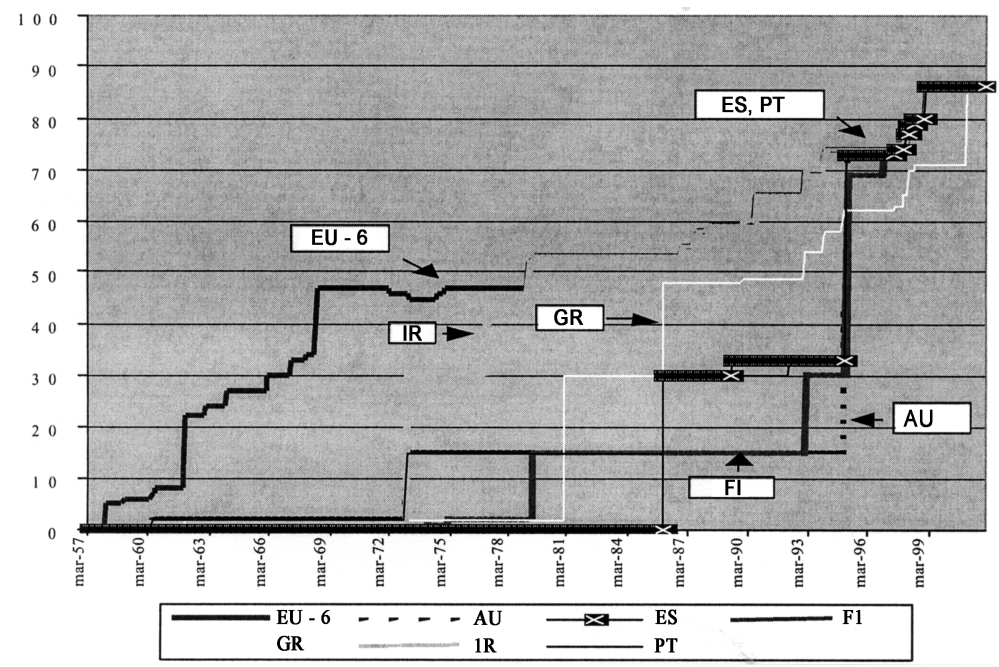


had joined this core group (Figure 3), while three other members have preferred to opt for a lower level of integration thus far (Figure 4). As mentioned, we do not consider here the ten conutries that joined the EU in 2004. For this reason, we will

Figure 4. Institutional Index of integration for Denmark, Sweden and United Kingdom taken individually (1957 - 2001).

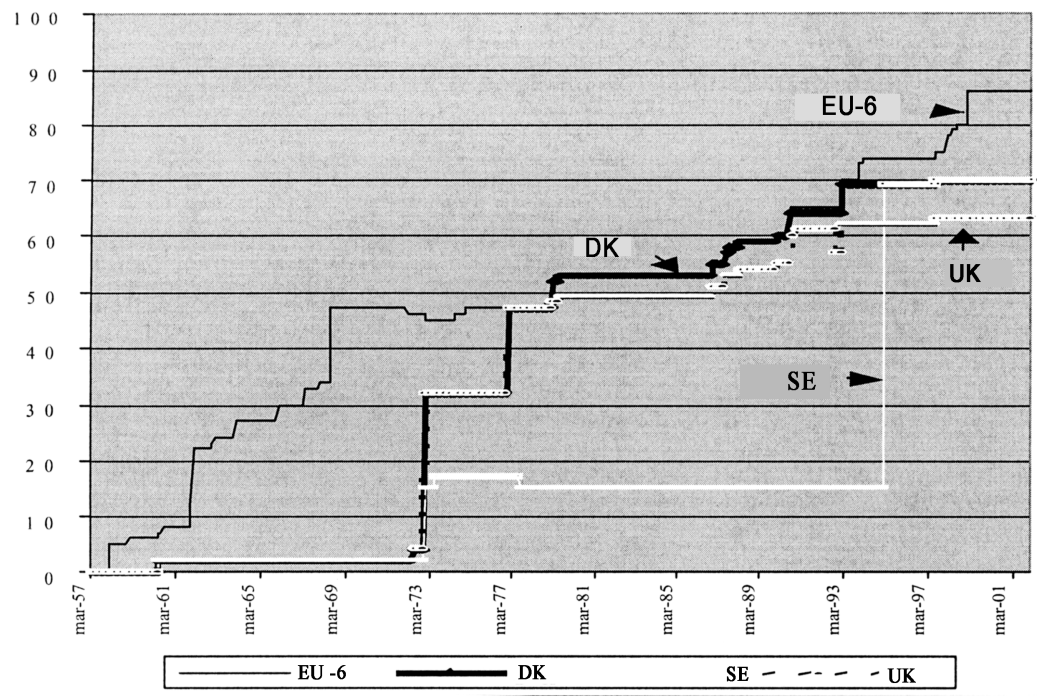

Figure 5. Institutional index of integration for Mercosur (1991-2001) as compared to EU 6 (1957-2001).

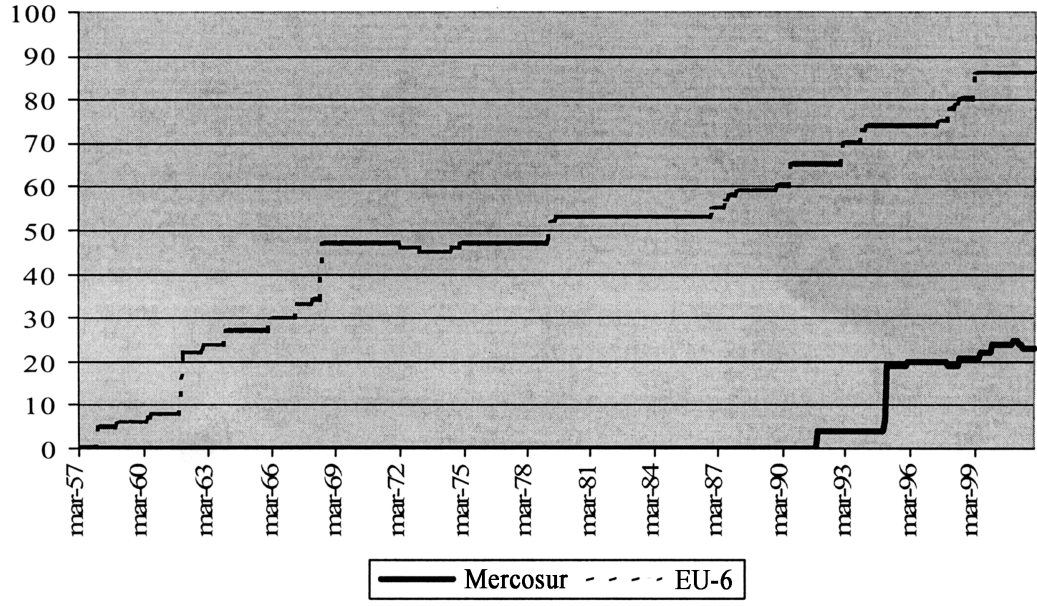

Notes: The four Mercosur member States and EU-6 are here taken as a whole $(1957=0$, highest score possible for regional integration: 100

Sources for Fig. 3.- 5.: Authors own calculations based on various sources and in line with methodology described in Section 2.1. 
therefore refer, hereafter, to either EU-6 as EU-15 conuntries.

Third, using EU-6 as the benchmark, we can distinguish three sub-periods in the process of regional integration (Figure 1). The first period, characterised by very quick integration, proceeds from March 1957 (Treaty of Rome) to July 1968 (completion of the customs union). By that time more than half of the overall institutional integration process had been already completed. In July 1968 the EU was indeed much more than a customs union, since it already had some genuine characteristics of subsequent Balassa stages. The second period can be identified between the start of the 1970s and the mid-1980s, and is characterised by sluggish integration (so-called "euro-scepticism"), with the noteworthy exception of the EMS start in March 1979. Finally, in the third, most recent period a new, considerable acceleration in regional integration can be observed: as a result, the EU/euro area can currently be classified somewhere between an EUN and a TEI.

If the core proposition discussed in this study is true - i.e., the proposition that regional institutional integration interacts with regional economic integration - one would expect that trends in EU economic integration between 1957 and 2001 follow a path similar to that we have tracked for institutional integration. This will be discussed in the subsequent sections.

\section{An application of the index to Mercosur}

Since the early 1990s, a process of revitalisation and renewal of Latin American sub-regional integration ${ }^{9}$ has accompanied the structural economic reforms being implemented in the countries of the region. Mercosur, created in 1991 between Argentina, Brazil, Paraguay and Uruguay, soon came to prominence for the economic area being developed in the Southern Cone of South America, with a population of over 220 million and a GDP in excess of USD 900 billion. Mercosur's final objectives were ambitious: to create a common market and to co-ordinate the economic policies of its member countries. Equally striking was the singlemindedness with which Mercosur pursued its objectives in the first half of the 1990s, which led to the satisfactory conclusion in December 1994 of what was known as the transition phase. Partly as a result of these institutional developments (see Eichengreen (1998) for other explaining factors), the share of intra-regional trade in aggregate Mercosur exports rose throughout the decade, from 9\% in 1990 to

\footnotetext{
${ }^{9}$ The process of regional integration in Latin America does not, in fact, start in the 1990s. Examples of regional integration in the earlier periods are the Cartagena Agreement founding the Andean Group (1969) and the Chaguaramas Treaty founding the Caribbean Community (1973).
} 
$25 \%$ in 1998 (see next section for greater detail). Despite the uncertainty in and setbacks to the process of integration caused by the 1999 devaluation of the Brazilian real and the Argentine crisis since in 2001-2002, Mercosur remains the core sub-regional arrangement in Latin America. Moreover, it is possible that Mercosur will be revitalised and deepened in the coming years, as a result of a new wave of initiatives in the aftermath of the Argentine crisis.

Despite its achievements, Mercosur ranks much lower than the EU in terms of degree of regional integration, with an index accounting for 23 out of 100 at the end of 2001 (i.e., a score comparable to that achieved by EU-6 already in the mid1960s). Using the EU as a yardstick, the index of institutional regional integration for Mercosur accounts for only one quarter of the EU index at the end of 2001 (see Figure 1.5). This can be attributed not only to the "quantity" of integration - i.e., the fact that Mercosur obtains high scores only as a free trade area and a customs union - but also to its "quality".

It is in the latter field - i.e., how the free trade area and customs union are actually implemented - that Mercosur might consider drawing some lessons from the European experience. First, differently from the EU, Mercosur countries not only can still keep their own tariffs for a list of exempted goods, but are empowered to withdraw from their commitments as both the Brazilian and Argentine experiences confirm. This reversibility is among the main reason why Mercosur still ranks below the EU of 1968 as a FTA/CU. Second, the Mercosur treaty is intergovernmental in nature, not supranational (see for instance Laird (1997)). As a result, Mercosur's decisions have no force as such and need to be implemented by corresponding national measures, with no obligation for Member States to comply with common market rules. There is indeed no supranational court through which either a member country or the Mercosur Secretariat can enforce treaty provisions on another member or a private party. This implies that the existence of several Mercosur bodies cannot be weighed as much as for EU bodies.

\section{Comparing Economic Integration in Europe and Latin America}

We now compile and analyse several indicators of economic integration that have been suggested by the OCA theory, as well as some other variables that have not been explicitly mentioned within this framework but which help complement a

\footnotetext{
${ }^{10}$ Seminal contributions to the OCA theory are Mundell (1961), McKinnon (1963), and Kenen (1969).
} 
more comprehensive definition of economic integration. ${ }^{10}$ The drawback is that only a more limited range of variables is available for Latin American countries than for European countries. The following are the variables we were able to collect and the rationale for including them in our analysis.

A first variable we look at is the volatility of the exchange rate. OCA theory implies that if real exchange rate variability is small and currencies are stable against each other, the cost of abandoning flexible exchange rate regimes or even adopting a common currency is lower. For the European country groupings we take the regional average of each country's moving average variance of the log difference of the real/nominal bilateral exchange rate vis-à-vis the de facto anchor currency, the Deutsche Mark as our measure of intra-regional exchange rate variability. For Latin America, being not able to identify an anchor country, we employ the same measure using each country's average bilateral exchange rates variability vis-à-vis all other regional currencies.

Second, as to trade integration and openness, OCA theory implies that different countries can benefit more from reducing or even eliminating exchange rate variability if they already trade strongly with each other. We employ two types of measures on the trade side: we measure the degree of regional trade integration as the ratio of intra-regional trade to total trade. A potential drawback of this measure is that this ratio may not increase even if intra-regional trade rises strongly because of an even higher growth rate in extra-regional trade. We therefore use the ratio of intra-regional trade to GDP as an indicator of trade openness.

Third, countries may benefit from financial market integration by allocating resources more efficiently and reducing transaction costs. Financial market integration permits also to cushion temporary adverse disturbances through capital inflows. Under a high degree of financial integration even modest changes in interest rates would elicit equilibrating capital movements across partner countries. This would reduce differences in interest rates, easing the financing of external imbalances. In this paper we employ two proxies for financial market integration. The first is the correlation of monthly equity market returns across countries. We also investigate the degree of financial market openness, which is defined as the ratio of equity market capitalisation to GDP for each country.

Fourth, interest rate convergence is used as a measure of the degree of similarity of the monetary policy stance across countries. The rationale for using this measure is that the higher the initial similarity of interest rates, the less is the cost for each country by moving to a common monetary policy. We test in the analysis both the 
correlation of nominal short-term interest rates and of short-term real interest rates, using CPI inflation rates as deflator.

Fifth, more economic integration should also enhance the convergence of income across countries and regions. Again, we refer to an argument of resource allocation in this regard: more integration and openness should lead to more mobility of factors of production, which may result in convergence of income levels. As a proxy, we use the real GDP per capita percentage difference to the regions average. The real GDP per capita numbers were obtained from the Summers and Heston (1988) database and interpolated for the past few years.

Sixth, a high degree of synchronisation of the business cycle across two countries indicates that the business cycle in each country is driven largely by common external shocks, or that the economies of the two countries are highly interdependent (Artis and Zhang, 1998a and 1998b). The higher synchronisation, the lower is the cost of pursuing common policies and deepening integration. Following Baxter and Stockman (1989), we use the cross-correlation of monthly industrial production series, de-trended by using a Hodrick-Prescott filter (with $\lambda=$ 14400) to measure the degree of synchronisation of the business cycle.

Finally, deepening institutional integration is most beneficial if inflation rates are already reasonably similar among the member states participating in the regional arrangement. Inflation convergence, for instance, is a key element of the Maastricht Treaty for the creation of a single European currency. We measure the convergence of inflation as the difference of the 12-month percentage changes in the consumer price indices, and alternatively as the correlation coefficient, for each country with the region's average.

\section{A. The development of economic integration in Europe and Latin America over time}

\section{Overview}

As a starting point, it is necessary to specify the country groupings and time periods we are focusing on. As for the index of institutional regional integration, we look at EU6 and Mercosur countries. In addition, for Europe we also look at the euro area, and for Latin America at a large subset of countries which we call "Latin America 11"11. For Europe, we consider the period 1957-2001 and the follow-ing six sub-periods:

\footnotetext{
${ }^{11}$ For the purposes of this paper, Latin America 11 includes Mercosur countries, the members of the Andean Community (Bolivia, Colombia, Ecuador, Peru and Venezuela), Chile and Mexico.
} 


\begin{tabular}{|c|c|}
\hline Sub-period & Main characteristics \\
\hline $\begin{array}{l}\text { March 1957- } \\
\text { August } 1971\end{array}$ & Bretton Woods system of fixed exchange rates \\
\hline $\begin{array}{l}\text { September } 1971 \text { - } \\
\text { February } 1979\end{array}$ & $\begin{array}{l}\text { Very volatile exchange rates; failed attempt to establish an exchange } \\
\text { rate mechanism (the "Snake"); major recession in 1973-75 }\end{array}$ \\
\hline $\begin{array}{l}\text { March } 1979 \text { - } \\
\text { August } 1987\end{array}$ & $\begin{array}{l}\text { "Soft ERM": introduction of EMS with frequent realignments, espe- } \\
\text { cially until } 1983\end{array}$ \\
\hline $\begin{array}{l}\text { September } 1987 \text { - } \\
\text { December } 1992\end{array}$ & $\begin{array}{l}\text { "Hard ERM": no realignments (apart from a realignment associated } \\
\text { to the lira entering the narrow ERM bad in January 1990) until the } \\
\text { EMS crisis in September 1992; integration of factor markets, culmi- } \\
\text { nating in the establishment of the European Single Market on } 1 \text { Jan- } \\
\text { uary } 1993\end{array}$ \\
\hline $\begin{array}{l}\text { January } 1993 \text { - } \\
\text { December } 1998\end{array}$ & $\begin{array}{l}\text { "Pre-EMU": Enhanced nominal convergence and run-up to mone- } \\
\text { tary union }\end{array}$ \\
\hline January 1999 onwards & European Monetary Union (EMU) \\
\hline
\end{tabular}

We can instead look only at a shorter time period (1980-2000) for Latin America due to limited data availability. We chose the following three sub-periods for the purpose of analysing the time changes of economic integration:

\begin{tabular}{cl}
\hline Sub-period & \multicolumn{1}{c}{ Main characteristics } \\
\hline January 1980 - & Latin American debt crisis; relatively moderate nominal volatility \\
December 1986 & Highly volatile exchange rates, and high rates of inflation or hyperinfla- \\
January 1987 - & tion for several Latin American countries \\
December 1993 & Re-structuring and stabilisation programmes in several economies; \\
January 1994 - & strengthening of the process of regional integration \\
December 2000 &
\end{tabular}

Table 2 lists the measures of economic integration of the above-described indicators of economic integration for the two regions and the different time periods. As expected, both EU-6 and the euro area are generally a much more integrated economic area than Latin America over time (not only than the selected 11 Latin American countries, but also than Mercosur countries). Overall, comparing the levels of economic integration emerging from the above tables and figures, one can conclude that the degree of economic integration in Latin America is roughly close to that in Europe in the 1960s and 1970s.

As Table 2 illustrates, exchange rate variability in Latin America has been substantially higher than in Europe (even with respect to the 1970s, a period characterised by high exchange rate variability in Europe as well). Since changes in the exchange rate arrangement have been of key importance for understanding the 
Table 2. Selected indicators of economic integration in Europe and Latin America.

\begin{tabular}{|c|c|c|c|c|c|c|c|c|c|c|c|c|}
\hline & & $\begin{array}{l}\text { Business } \\
\text { cycle } \\
\text { correlation }\end{array}$ & $\begin{array}{c}\text { Real per } \\
\text { capita GDP } \\
\% \text { difference }\end{array}$ & $\begin{array}{l}\text { Inflation } \\
\% \text { rate } \\
\text { correlation }\end{array}$ & $\begin{array}{c}\text { Real interes } \\
\text { rate } \\
\text { correlation }\end{array}$ & $\begin{array}{l}\text { Nominal } \\
\text { interest rate } \\
\text { correlation }\end{array}$ & $\begin{array}{c}\text { Real } \\
\text { exch. rate } \\
\text { volatility }\end{array}$ & $\begin{array}{c}\text { Nominal } \\
\text { exch. rate } \\
\text { volatility }\end{array}$ & $\begin{array}{c}\text { Trade } \\
\text { integration }\end{array}$ & $\begin{array}{c}\text { Trade } \\
\text { openness }\end{array}$ & $\begin{array}{c}\text { Financial } \\
\text { market } \\
\text { integration }\end{array}$ & $\begin{array}{c}\text { Financial } \\
\text { market } \\
\text { openness }\end{array}$ \\
\hline & $1957-70$ & 0.212 & 23.338 & 0.209 & 0.334 & 0.537 & 9.083 & 4.633 & 61.080 & 26.990 & NA & NA \\
\hline \multirow{7}{*}{ Euro area } & $1971-78$ & 0.533 & 19.845 & 0.470 & 0.320 & 0.240 & 18.878 & 16.629 & 63.211 & 32.976 & 0.189 & 7.354 \\
\hline & $1979-87$ & 0.298 & 18.715 & 0.705 & 0.242 & 0.273 & 12.462 & 10.868 & 63.012 & 37.724 & 0.140 & 9.466 \\
\hline & $1988-92$ & 0.309 & 17.113 & 0.353 & 0.361 & 0.482 & 10.239 & 7.704 & 70.602 & 42.039 & 0.466 & 15.625 \\
\hline & $1993-98$ & 0.417 & 15.213 & 0.335 & 0.512 & 0.596 & 10.470 & 9.075 & 66.113 & 40.399 & 0.633 & 31.419 \\
\hline & $1999-2001$ & 0.334 & 14.073 & 0.692 & 0.483 & 1.0 & 4.235 & 0.0 & 60.426 & 45.524 & 0.486 & 81.629 \\
\hline & $1957-70$ & 0.282 & 7.612 & 0.256 & 0.462 & 0.669 & 7.219 & 3.937 & 62.381 & 30.442 & NA & NA \\
\hline & $1971-78$ & 0.791 & 6.423 & 0.508 & 0.343 & 0.473 & 14.923 & 14.066 & 65.749 & 39.062 & 0.514 & 8.931 \\
\hline \multirow[t]{4}{*}{ EU 6} & $1979-87$ & 0.513 & 5.168 & 0.889 & 0.228 & 0.723 & 8.344 & 7.557 & 64.765 & 44.485 & 0.336 & 11.456 \\
\hline & $1988-92$ & 0.368 & 5.172 & 0.368 & 0.443 & 0.744 & 7.605 & 5.525 & 69.865 & 47.291 & 0.698 & 20.237 \\
\hline & $1993-98$ & 0.515 & 4.887 & 0.539 & 0.654 & 0.804 & 8.220 & 6.746 & 65.790 & 42.899 & 0.727 & 37.353 \\
\hline & $1999-2001$ & 0.576 & 4.722 & 0.817 & 0.499 & 1.0 & 3.096 & 0.0 & 60.503 & 50.956 & 0.599 & 85.552 \\
\hline LATIN & $1980-86$ & 0.469 & 32.091 & 0.194 & 0.077 & 0.093 & 106.05 & 90.35 & 17.026 & 6.236 & NA & NA \\
\hline AMERICA & $1987-93$ & 0.240 & 30.154 & 0.204 & -0.015 & 0.003 & 78.24 & 75.62 & 19.776 & 7.844 & 0.200 & NA \\
\hline 11 & $1994-2000$ & 0.320 & 32.955 & 0.311 & -0.014 & 0.329 & 31.89 & 33.33 & 27.630 & 10.200 & 0.350 & NA \\
\hline \multirow{3}{*}{$\begin{array}{l}\text { MERCO- } \\
\text { SUR }\end{array}$} & $1980-86$ & 0.687 & 23.866 & 0.321 & 0.185 & 0.094 & 78.30 & 67.36 & 13.458 & 3.709 & NA & NA \\
\hline & $1987-93$ & 0.427 & 21.876 & 0.279 & -0.008 & 0.010 & 91.88 & 92.68 & 17.382 & 5.924 & 0.202 & NA \\
\hline & $1994-2000$ & 0.458 & 25.825 & 0.433 & -0.015 & 0.295 & 23.42 & 22.15 & 30.311 & 8.412 & 0.384 & NA \\
\hline
\end{tabular}

Note: Correlation and difference measures are relative to region average. See text for definition of variables. 
integration process in Europe, in the next sub-section 3.2.2 we provide a more detailed discussion on the development of exchange rates. Regional trade integration and openness are in Europe much larger than in Latin America on average. The interest rates and inflation rates show a much higher degree of comovement in Europe than in Latin America. In particular, the correlation of nominal interest rates has been around $60 \%$ within the euro area during the preEMU period, but only around $30 \%$ for the Latin American countries. Finally, the higher degree of economic integration is also reflected in the integration of financial markets. Equity market return correlations in Europe are at around 50\% or higher, which is around twice as high as the correlation in Latin America.

\section{B. Further evidence on exchange rate variability}

Changes in the exchange rate arrangement have been very important for understanding the institutional integration process in Europe. The measure of nominal and real exchange variability briefly outlined in section 3.1 and Table 2 provide a useful insight in this respect. In this sub-section we provide a more detailed discussion of the development of exchange rates dynamics using a more elaborated indicator of exchange rate variability, which has been extensively used in the literature. ${ }^{12}$

Bilateral exchange rate variability between currency $i$ and $j\left(\sigma^{i j}\right)$ is defined here as the moving sample standard deviation of the growth rate of the bilateral exchange rate (first differences of the logarithmic exchange rate or exchange rate percentage change):

$$
\sigma^{i j}=\left[\frac{1}{n} \sum_{k=1}^{n}\left(e_{t-k}-\bar{e}_{t}\right)^{2}\right]^{0.5}
$$

where $e$ is the monthly change in nominal/real bilateral exchange rate while $\mathrm{n}$ is the order of the moving standard deviation. In the computation $n$ has been set at 4 in order not to excessively smooth the monthly exchange rate variability. In order to have an indicator of the exchange rate variability within EU or Latin American country groupings, we construct a weighted average (using trade weights) of the above measures using each bilateral variability. For example, in the case of the

\footnotetext{
${ }^{12}$ See Kenen and Rodrik (1986), Koray and Lastrapes (1989), Chowdhury (1993) and Arize (1996 and 1999).
} 
euro area country grouping, the real (or nominal) exchange rate variability indicator $(E V I)$ is constructed as follows ${ }^{13}$ :

$$
E V I_{t}=\sum_{k \neq 1, i j=1}^{55} w_{t}^{i j} \sigma_{t}^{i j}
$$

Table 3 and Figure 6.a present the indicators of nominal and real exchange rate variability for the euro area. ${ }^{14}$ A visual inspection of Figure 6a reveals that between 1957 and 1998 real exchange rate variability has always exceeded nominal exchange rate variability. This is indicative of the fact that in the EU an effort to pursue nominal convergence (i.e., one major requirement for successful regional integration) was in place. Although with different levels of commitment and different paths over time, EU Member States with higher inflation rates accepted swings in, and an appreciation of, their real effective exchange rate. This served as an instrument to pursue disinflation and re-structure domestic industry exposed to international competition. Sometimes this led to unsustainable trends in the real exchange rates, which in the ERM experience were then adjusted though usually only partially and ex-post by means of so-called "realignments" of the nominal exchange rates.

Table 3. Indicator of Nominal and Real Exchange Rate Variability in the EU

\begin{tabular}{cccccccc}
\hline Country & $\begin{array}{c}\text { Whole } \\
\text { period }\end{array}$ & $\begin{array}{c}\text { Bretton } \\
\text { Woods }\end{array}$ & $\begin{array}{c}\text { Post BW } \\
\text { pre ERM }\end{array}$ & Soft ERM & Hard ERM & $\begin{array}{c}\text { Pre } \\
\text { EMU }\end{array}$ & EMU \\
Group & 1957 & $1957: 3$ & $\begin{array}{c}1971: 8 \\
1979: 2\end{array}$ & $\begin{array}{c}1979: 3 \\
1987: 8\end{array}$ & $\begin{array}{c}1987: 9 \\
1992: 12\end{array}$ & $\begin{array}{c}1993: 1 \\
1998: 12\end{array}$ & $1999: 1$ \\
& 2001 & $1971: 7$ & $19791-5$ \\
\hline EU 6 & & & & & & & \\
Real & 0.0096 & 0.0087 & 0.0156 & 0.0089 & 0.0079 & 0.0092 & 0.0032 \\
Nominal & 0.0074 & 0.0048 & 0.0146 & 0.0081 & 0.0063 & 0.0078 & 0.0000 \\
Euro Area & & & & & & & \\
$\quad$ Real & 0.0105 & 0.0095 & 0.0165 & 0.0100 & 0.0091 & 0.0102 & 0.0033 \\
Nominal & 0.0080 & 0.0050 & 0.0151 & 0.0090 & 0.0072 & 0.0088 & 0.0003 \\
EU & & & & & & & \\
Real & 0.0163 & 0.0138 & 0.0226 & 0.0177 & 0.0146 & 0.0163 & 0.0098 \\
Nominal & 0.0100 & 0.0046 & 0.0161 & 0.0131 & 0.0101 & 0.0119 & 0.0066 \\
\hline
\end{tabular}

\footnotetext{
${ }^{13}$ In the euro area sample there are 12 countries but $\mathrm{i}$ and $\mathrm{j}$ goes from 1 to 11 because Belgium and Luxembourg represent just one country, so there are 55 bilateral real exchange rates and trade weights.

${ }^{14}$ Note that Table 3 also includes the EU-6 and EU-15 while Figure 4 only presents the exchange rate variability for the euro area.
} 


\section{Figure 6a.}

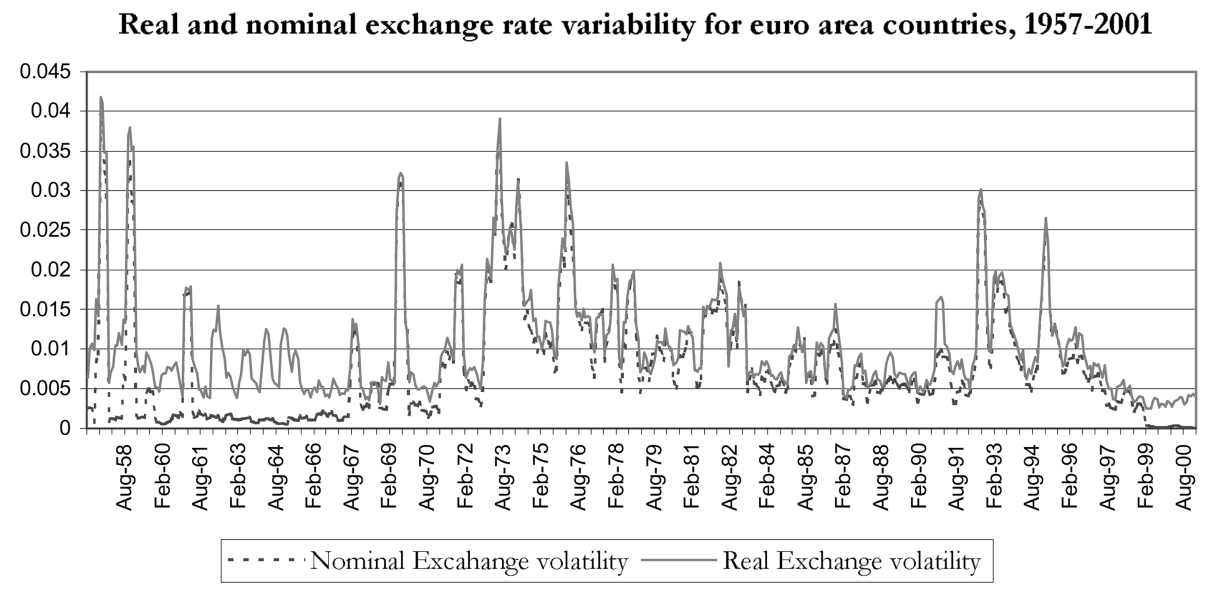

Figure 6b.

Real and nominal exchange rate variability for Latin America 11 countries, 1980-2001

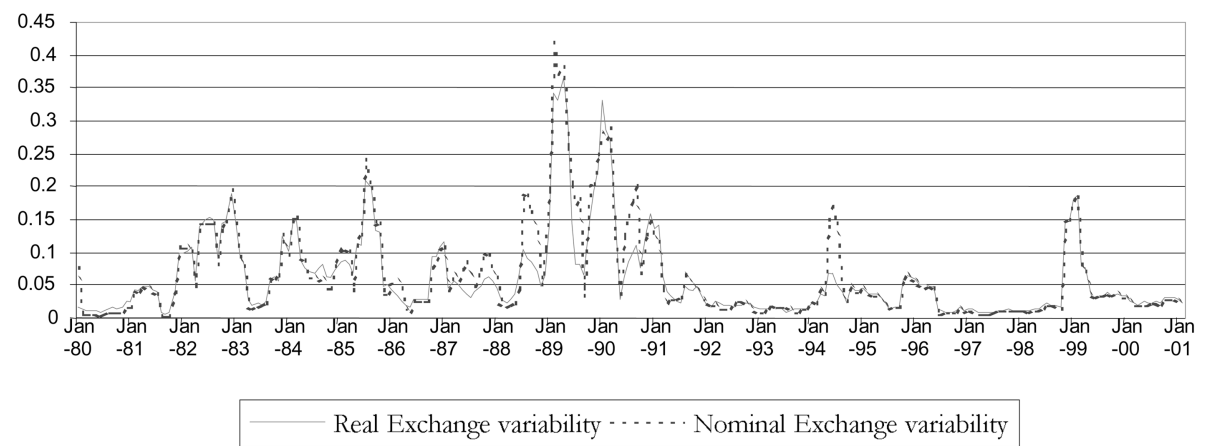

Besides this general indication, we can distinguish a few sub-periods. A striking feature of fixed but adjustable exchange rates under the Bretton Woods system is that it did not shield European countries from some "occasional" adjustments in exchange rate parities and from some significant real exchange rate variability. The subsequent sub-period, following the collapse of Bretton Woods and prior to the ERM experience, is characterised by the highest overall nominal and real exchange rate variability. During the subsequent two sub-periods - i.e. the "soft-and the hardERM" - variability declined albeit unevenly and with a very sizeable swing back in the run-up to the 1992-ERM crisis and its aftermath. Nominal exchange rate variability then disappeared with the introduction of the euro in January 1999, while real exchange rate variability has thus far declined to its lowest levels ever. 
Table 4. Indicator of Nominal and Real Exchange Rate Variability in Mercosur and Latin America

\begin{tabular}{lcccccc}
\hline \multicolumn{1}{c}{ Country } & \begin{tabular}{c} 
Whole period \\
\multicolumn{1}{c}{ 1980:1 }
\end{tabular} & $\mathbf{1 9 8 0 : 1}$ & $\mathbf{1 9 8 3 : 4}$ & $\mathbf{1 9 8 9 : 1}$ & $\mathbf{1 9 9 2 : 2}$ & $\mathbf{1 9 9 8 : 1 1}$ \\
& $\mathbf{2 0 0 1 : 2}$ & $\mathbf{1 9 8 3 : 3}$ & $\mathbf{1 9 8 8 : 1 2}$ & $\mathbf{1 9 9 2 : 1}$ & $\mathbf{1 9 9 8 : 1 0}$ & $\mathbf{2 0 0 1 : 2}$ \\
\hline $\begin{array}{l}\text { Mercosur } \\
\text { Real }\end{array}$ & 0.0624 & 0.1506 & 0.0437 & 0.1884 & 0.0114 & 0.0598 \\
$\begin{array}{l}\text { Nominal } \\
\text { Mercosur and }\end{array}$ & 0.0673 & 0.838 & 0.0522 & 0.1988 & 0.0153 & 0.0585 \\
$\begin{array}{l}\text { associate members } \\
\text { Real }\end{array}$ & & & & & & \\
$\begin{array}{l}\text { Nominal } \\
\text { Latin America }\end{array}$ & 0.0653 & 0.1214 & 0.1433 & 0.1477 & 0.0116 & 0.0474 \\
$\begin{array}{l}(11 \text { countries) } \\
\text { Real }\end{array}$ & 0.0880 & 0.0803 & 0.0767 & 0.1742 & 0.0122 & 0.0261 \\
Nominal & & & & & & \\
\hline
\end{tabular}

Table 4 focuses on real exchange rate variability in Latin America, distinguishing between Mercosur, Mercosur and its associate members (Chile and Bolivia), and Latin America 11 (the latter is also represented in Figure 6b). The Table illustrates that in the period 1980-2001 real exchange rate variability in Mercosur was almost 7 times higher than in EU-6, while nominal exchange rate variability was nearly 10 times higher. During times of crisis such variability rose to much higher levels, but such episodes are not discussed in this paper. The more recent episode of exchange rate instability in the region is also excluded from our sample. An important difference with respect to Europe is that in Latin America nominal exchange rate variability generally exceeds real exchange rate variability. This is indicative of the fact that in Latin America there was no systematic effort to pursue nominal convergence over time.

Table 4 also shows that exchange rate variability in Mercosur displays some very marked changes between sub-periods. In particular there are two "tranquil periods" - such as from April 1983 to December 1988, and from February 1992 to October 1998 - during which variability was remarkably lower than in the other "crises periods." In particular, the levels of both nominal and real exchange rate variability during the second "tranquil period" (i.e., the period when regional integration proceeded at the fastest speed within Mercosur) are close to the European levels.

The latter observation indicates that high exchange rate variability is not necessarily embedded in the Latin American economic and financial system. There were in fact two periods in which successful stabilisation was achieved and 
maintained for some time. However, a climate of sustained low exchange rate variability also requires supporting policies in diverse areas and institutional choices: an issue that will be discussed in the next sections. All in all, Latin America currently fulfils the optimum currency area (OCA) criteria investigated here to a lesser extent not only than the European Union (EU) today, but in some cases even than the EU at the beginning of its regional integration process. ${ }^{15}$

\section{Comparing Institutional and Economic Integration: A Cluster Analysis}

We now turn to the main question raised in this paper: testing the hypothesis that institutional integration interacts with economic interdependence at the regional level. We examine and compare the degree and dynamics of integration in both Europe and in Latin America.

After explaining the methodology in Section 4.1, we address three types of questions. A first question is: how really integrated are the countries within Europe and Latin America from an economic viewpoint? Can one identify homogenous groups of countries within regions? And, if so, what makes countries within groups similar? Second, by looking at a relatively long time horizon (from 1957 onwards for Europe and from 1980 onwards for Latin America) we investigate the dynamics of the process of economic integration within both regions. Which periods have experienced a particularly strong increase in economic integration? While these questions are addressed in Section 4.2, in Section 4.3 we analyse the link between institutional integration, as described in Section 2 above, and economic integration in Europe in comparison with Latin America.

\section{A. Methodology}

The purpose of the cluster analysis is to detect natural groupings, or "clusters", among countries. The way the cluster analysis is detecting such groupings is by measuring the dissimilarity among the countries and assigning each country to a particular group by using a distance metric. The distant metric we employ in this analysis is the Euclidean distance

\footnotetext{
${ }^{15}$ Fiscal dominance, insufficient trade integration and business cycle synchronisation, and weaknesses in the financial system are usually listed as crucial deficiencies. This type of conclusion can be found in most of the literature: among others, Bayoumi and Eichengreen (1994), Eichengreen (1998), Berg, Borensztein and Mauro (2000), and Belke and Gros (2002).
} 


$$
D(i, j)=\sqrt{\sum_{k=1}^{p}\left(x_{k i}-x_{k j}\right)^{2}}
$$

where $\mathrm{D}(\mathrm{i}, \mathrm{j})$ measures the dissimilarity between country $\mathrm{i}$ and country $\mathrm{j}$ for all economic integration characteristics $\mathrm{k}$.

There are two different methods of forming the clusters or groupings. First, one can partition the countries into a predetermined number of clusters. This implies that each country is assigned by iteration to that group to which it is most similar. The second alternative is the hierarchical clustering method. ${ }^{16}$ We use this second alternative, more precisely an "agglomerative" hierarchical clustering method. In essence, this method starts by creating a number of clusters $\mathrm{N}$ that is equal to the number of countries in the sample. The method proceeds by first combining those two countries that are most similar, and then continuing in the same fashion till all countries belong to the same group or to a single group out of a pre-specified number of groups. We use the average of each group when comparing the Euclidean distance of two different groups. This ensures that the shape of the clusters is reasonably compact.

A further relevant issue is the normalisation of the data. As a starting point, we wish to give equal weight to each of the economic integration variables $\mathrm{k}$. Under the assumption that the variables are each distributed normally, we need to transform the data to have the same mean and standard deviation. We chose a mean of zero and a standard deviation of unity.

\section{B. The degree and dynamics of regional economic integration}

\section{Results for the EU}

Figure A2.1 in Appendix 2 shows the cluster analysis dendrograms for the fifteen EU countries and the six sub-periods specified in Section 3.2.1. The dendrograms show in which order and at what degree of dissimilarity countries have merged together.

The dendrograms allows us to identify a trend since the 1950s. First, the degree of economic heterogeneity was generally much higher in Europe between the 1950s and 1970s. This can be seen from the size of the Euclidean distance on the

\footnotetext{
${ }^{16}$ See Kaufman and Rousseeuw (1990) and Gordon (1999) for a detailed analysis of cluster analysis methodology and the different underlying choices a modeller has to take.
} 
vertical axis. It is also less clear-cut to identify clusters in the earlier periods than in the later periods.

A second interesting result is that the countries forming clusters have changed over time, in some cases drastically. More specifically, between the 1950s and the end of the 1970s integration seems to have been strongly related to the geographic location and distance of the countries to each other. This point is clearly illustrated for the period 1971-79. In this period, the country pairs that were most integrated with each other were usually direct geographic neighbours: Austria, Germany and Denmark; Belgium and the Netherlands; Spain and Portugal; and Greece and Italy. By contrast, since the 1980s clusters correspond more closely to institutional arrangements, in particular the participation in the ERM and EMU, than to geographic location.

This suggests that EU countries have become increasingly homogenous over time, while the forming of clusters has gradually more been based on institutional factors than on geographic factors (Figure 7).

To investigate these general findings in greater detail, Table 5 shows the degree of economic integration for various country groups and clusters. The table shows the average dissimilarity, based on the normalised Euclidean distance, for each group of countries with the EU average. A smaller number implies a lower degree of dissimilarity and, therefore, a higher degree of integration.

First, core EMU countries (core EMU6 cluster) have always been the most integrated and also further deepened their integration over time. By contrast, the

Figure 7. Real Integration versus Nominal Integration in Europe (1957-2000).

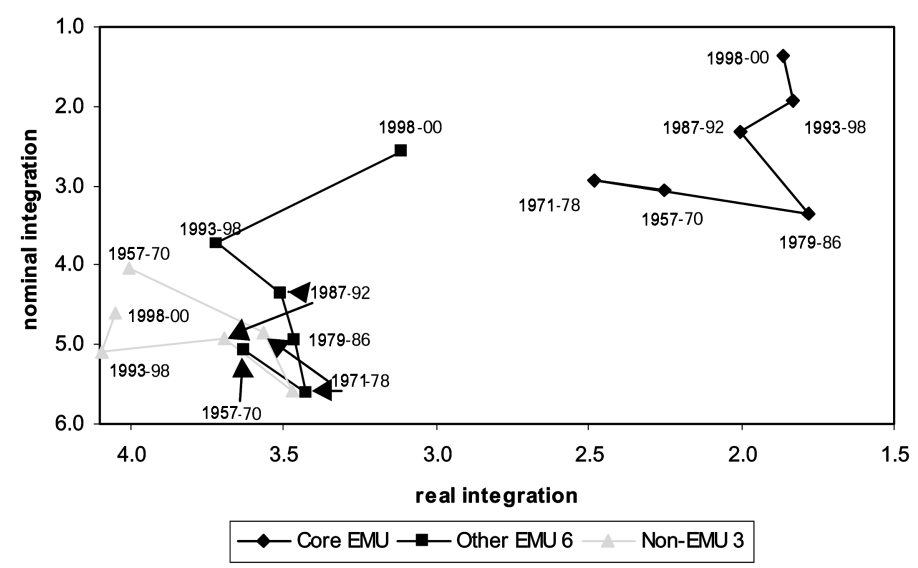

N.B.: The lower the values on the axes, the higher integration.

Core EMU refers to EU-6 founding Member States. Other EMU-6 comprises the other euro area Member States. Non-EMU countries are Denmark, Sweden and UK. 
non-EMU cluster has not managed to intensify its degree of integration over time. The most interesting case may be the "other" EMU6 cluster of countries that joined the integration process somewhat later. This cluster includes geographically diverse countries that had the lowest degree of integration in the 1950s and 1960s. However, since the 1970s these countries showed the fastest rate of integration.

A second important finding is that the degree of nominal economic integration has been significantly faster than real integration in Europe over the past 50 years (see Table 5 and Figure 7). EMU countries were initially more similar with regard to real economic variables than to their nominal counterparts. Real integration

Table 5. Measuring Economic Integration in Europe

\begin{tabular}{|c|c|c|c|c|}
\hline & EU15 & $\begin{array}{c}\text { Core } \\
\text { EMU 6 }{ }^{1}\end{array}$ & $\begin{array}{c}\text { Other } \\
\text { EMU } 6^{2}\end{array}$ & $\begin{array}{l}\text { Non-EMU } \\
\text { cluster }^{3}\end{array}$ \\
\hline \multicolumn{5}{|c|}{ Total economic integration $^{4}$} \\
\hline $1957-70$ & 4.85 & 3.65 & 6.12 & 5.68 \\
\hline $1971-78$ & 5.12 & 3.85 & 6.45 & 6.00 \\
\hline $1979-87$ & 5.15 & 3.90 & 6.00 & 6.64 \\
\hline $1988-92$ & 4.67 & 3.23 & 5.49 & 6.26 \\
\hline $1993-98$ & 4.34 & 2.56 & 4.91 & 6.48 \\
\hline 1999-2001 & 4.02 & 2.64 & 4.04 & 6.40 \\
\hline \multicolumn{5}{|c|}{ Real economic integration ${ }^{5}$} \\
\hline $1957-70$ & 3.08 & 2.25 & 3.63 & 4.00 \\
\hline $1971-78$ & 2.95 & 2.48 & 3.43 & 3.56 \\
\hline $1979-87$ & 2.74 & 1.78 & 3.46 & 3.47 \\
\hline $1988-92$ & 2.88 & 2.00 & 3.51 & 3.69 \\
\hline $1993-98$ & 3.02 & 1.83 & 3.71 & 4.09 \\
\hline 1999-2001 & 2.80 & 1.86 & 3.11 & 4.05 \\
\hline \multicolumn{5}{|c|}{ Nominal economic integration 6} \\
\hline $1957-70$ & 3.84 & 3.05 & 5.07 & 4.04 \\
\hline $1971-78$ & 4.23 & 2.95 & 5.60 & 4.85 \\
\hline $1979-87$ & 4.32 & 3.35 & 4.95 & 5.58 \\
\hline $1988-92$ & 3.63 & 2.33 & 4.35 & 4.93 \\
\hline $1993-98$ & 3.33 & 1.93 & 3.71 & 5.10 \\
\hline 1999-2001 & 2.62 & 1.38 & 2.57 & 4.59 \\
\hline
\end{tabular}

Note: As explained in the text, integration is measured as the average of the normalised Euclidean distance of the variables. Therefore, a smaller number indicates less dissimialrity and hence higher integration.

${ }^{1}$ Core EMU6 are: Belgium/Luxemburg, France, Germany, Italy, Netherlands

${ }^{2}$ Other EMU6 are: Austria, Finland, Greece, Ireland, Italy, Portugal, Spain

${ }^{3}$ Non-EMU cluster are: Denmark, Swdedn, UK

${ }^{4}$ includes 7 variables: business cycle convergence, inflation difference, real interest rate convergence, real exchange rate volatility, trade integration, financial market integration, real per capita GDP convergence 5 indlueds 3 variables: business cycle convergence, trade integration, real per capita GDP convergence ${ }^{6}$ includes 4 varialbes: inflation difference, real interest rate convergence, real exchange rate volatility, financial market integration 
progressed and reached a high level by the late 1970s and since then the deepening has slowed. By contrast, nominal volatilities increased and nominal integration fell during the 1970s with the breakdown of the Bretton Woods System. However, the economic integration process in Europe in the 1980s and 1990s has mainly been driven by stronger integration among inflation rates, interest rates, exchange rates and financial markets.

These findings strongly point at institutional factors as the driving force of European economic integration: countries at the centre of the institutional integration process have also been those that have integrated most strongly economically.

\section{Results for Latin America}

Looking at the dendrograms of the cluster analysis (Figure A.2.2 in Appendix 2) reveals that economic integration in Latin America takes still place along geographic lines. The countries most integrated with each other are (i) Argentina, Uruguay and Chile; (ii) Brazil, Paraguay and Peru; (iii) Colombia and Venezuela.

Mexico, Bolivia, and Ecuador are among the least economically integrated countries in Latin America. This is likely to be partly explained by the specific economic characteristics of some of these countries, and also partly by their geographic location. Mexico stands out in particular. It is intuitively convincing that Mexico is one of the least integrated as it is more integrated with the US economy than with the rest of Latin America.

Turning to the Euclidean measure of integration gives an interesting picture about the time dynamics of the economic integration process in Latin America. Table 6 shows the measure of integration for all Latin America 11 countries as well as for the six countries of Mercosur plus associates. The most interesting information we obtain from this table is that the deepening of economic integration has been driven by integration of the nominal economic variables, such as less nominal and real exchange rate variability, more inflation and interest rate convergence and a higher degree of financial market integration. Real integration through the intensification of business cycle co-movements and trade has been markedly slower. This point is also illustrated in Figure 8, which graphs the nominal integration measure against the real one.

Moreover, economic integration among the four Mercosur countries plus two associate countries has reached a higher level than in Latin America as a whole. The period 1987-93 also deserves a special mention in this context. Table 6 shows 
Table 6. Measuring Economic Integration in Latin America

\begin{tabular}{lcc}
\hline & $\begin{array}{c}\text { Latin America } \\
11 \text { countries }^{1}\end{array}$ & $\begin{array}{c}\text { Mercosur } \\
\text { countries }^{2}\end{array}$ \\
\hline Total economic integration $^{3}$ & & \\
1980-86 & 2.44 & 2.13 \\
$1987-93$ & 2.29 & 2.11 \\
1994-2000 & 1.87 & 1.64 \\
Real economic integration $^{4}$ & & \\
1980-86 & 1.19 & 0.98 \\
1987-93 & 1.21 & 1.10 \\
1994-2000 & 1.12 & 0.95 \\
Nominal economic integration $^{5}$ & & \\
1980-86 & 1.86 & 1.63 \\
1987-93 & 1.86 & 1.66 \\
1994-2000 & 1.28 & 0.98 \\
\hline
\end{tabular}

Note: As explained in the text, integration is measured as the average of the normalised Euclidean distance of the variables. Therefore, a smaller number indicates less dissimialrity and hence higher integration.

${ }^{1}$ Latin America 11 are: Argentina, Bolivia, Brazil, chile, Colombia, Ecuador, Mexico, Paraguary, Peru, Uruguay, Venezuela

${ }^{2}$ Mercosur are: Argentina, Brazil, Paraguay, Uruguay

${ }^{3}$ includes 6 variables: business cycle convergence, inglation convergence real interest rate convergence, real exchange rate volatility, trade integration, financial market integration

${ }^{4}$ includes 2 variables: business cycles convergence, trade integration

${ }^{5}$ includes 4 variables: inflation difference, real interest rate convergence, real exchange rate volatillity, financial market integration

Figure 8. Real Integration versus Nominal Integration in Latin America (1980-2000).

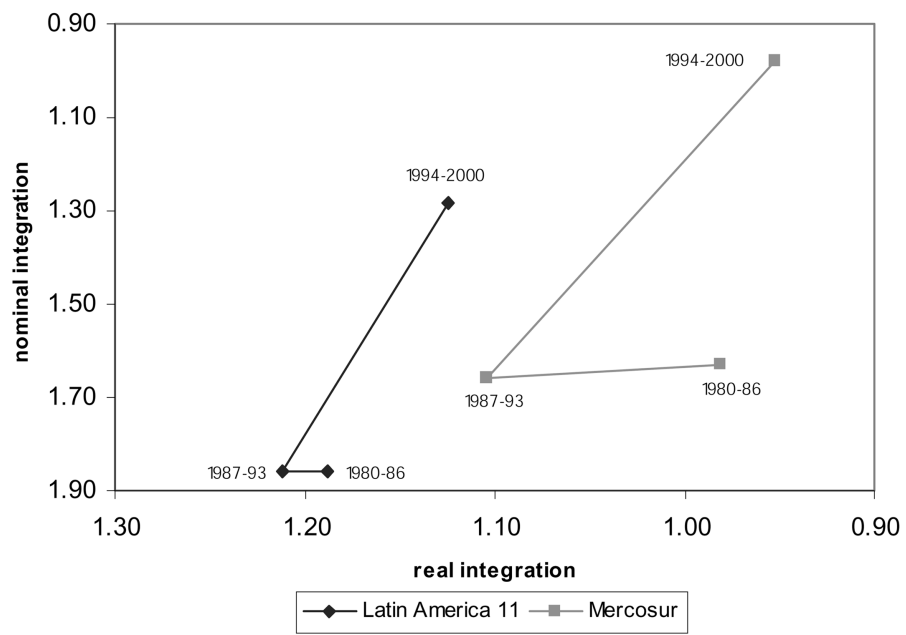

N.B.: $\quad$ The lower the values on the axes, the higher integration.

that the integration process came to a temporary halt during this period as none of the integration measures deepened throughout these seven years. This most likely 
is explained by the difficult economic conditions present during that time as numerous Latin American countries suffered under high inflation rates, slow growth and substantial exchange rate variability.

On the whole, the findings of the cluster analysis show that both Latin America and Europe have become more integrated over time. In particular, the integration process of real variables (business cycle, trade and income) is generally much slower than the integration process of nominal variables (exchange rates, inflation, interest rates, and financial markets). This is a result that one would expect, given the fact that the real integration process of economies is generally much slower as it partly requires the mobility and built-up of physical factors of production. It is relatively more feasible for policy-makers to achieve a convergence of inflation rates and interest rates across countries than to achieve a closer co-movement of business cycles and trade.

\section{Interaction between institutional and economic integration: some lessons for Latin America from the European experience}

A compelling finding of the analysis conducted in the previous section is that economic integration in Europe occurred along geographic lines in the earlier periods, whereas it took place mainly along institutional lines since the 1980s. Countries that were most closely committed to European institutional co-operation also integrated more quickly than those joining the various stages of the institutional process (e.g. ERM and monetary union) only later or not at all.

This suggests that institutional integration indeed had an important impact on economic integration in Europe. This is confirmed by Figure 9, which uses the institutional index of regional integration constructed in Section 3 for EU-6 countries and shows that economic integration was slower or even halted during periods, such as the 1970s, when progress in institutional integration was slow. By contrast, economic integration was faster when institutional integration deepened significantly, for instance in the late 1980s and 1990s. For the Mercosur countries (Figure 10), the degree of institutional integration is still much lower than in Europe, although some progress was made in the 1990s.

One of the key lessons from the European experience for Latin America is therefore that intensifying institutional integration, such as for instance through the creation of a common market and the co-operation of monetary and exchange rate policies, indeed plays an important role in deepening and accelerating the process of regional economic integration. The importance of deepening institutional 
Figure 9. Institutional versus eoonomic integration in Europe, 1957-2000

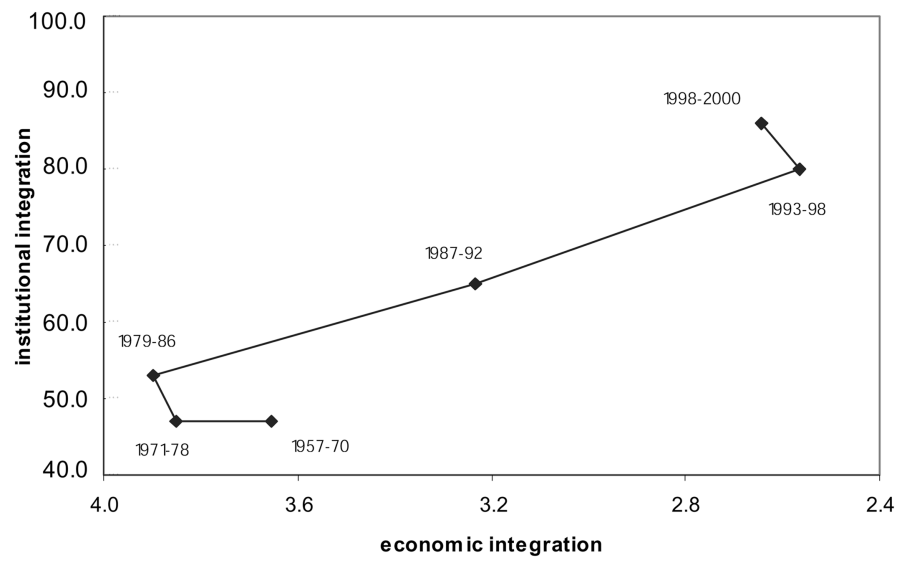

Figure 10. Institutional versus Economic Integration in Mercosur countries, 1980-2000.

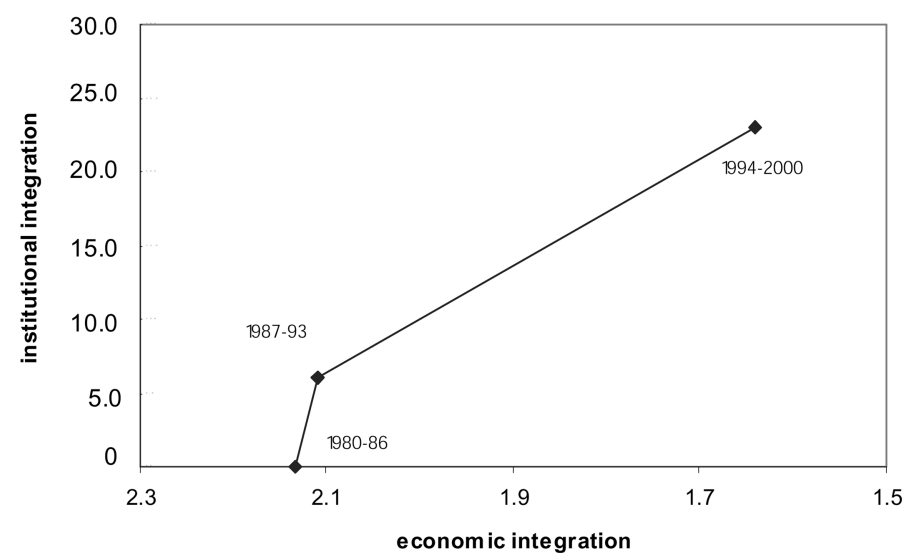

N.B.: $\quad$ The lower the values in Figures 9 and 10, the higher the degree of economic integration.

integration for economic integration in Europe can therefore be taken as a valuable example for the future path of integration in Latin America.

\section{Concluding Remarks}

This paper has presented a novel indicator of regional institutional integration capturing the most distinctive feature of European regional integration: its systematic and incremental approach. An ever-larger group of European countries have progressed along the five Balassa "stages" of regional integration: i.e., free trade, custom unions, common market, economic union, and total economic 
integration. Regional institutional integration in Latin America is instead relatively recent and still in the starting stages.

The paper then presented a set of indicators of economic integration -- suggested by the optimum currency area (OCA) theory -- capturing several measures of real, financial and monetary integration in a given region. These indicators show that Latin America is currently less economically integrated not only than the European Union today, but in some cases even than the EU at the beginning of its regional integration process.

In the latter part, a cluster analysis illustrates that at least throughout the European experience -- the link between institutional and economic integration has worked both ways. The more institutional integration went beyond the creation of a customs union and moved towards a common market and an economic and monetary union, the deeper economic integration turned out. Increasing economic integration in turn corroborated and sustained the process of institutional integration.

While we have not explicitly tested for any direction of causality, in the EU experience there is clearly a significant interaction between: (a) the depth of institutional integration; and (b) actual economic integration.

Regarding the influence of (a) on (b), one of the most important characteristics was the steady commitment over time. European integration has indeed moved far beyond the objective of a free trade area in the course of the last fifty years. Europe is now a single market and a monetary union. In the EU goods, services, capital and workers are allowed to move freely. Subsidies and regulations, favouring domestic producers are prohibited. The fundamental laws governing economic activity (whether banking, or industrial production, or consumer protection) are issued by the Union itself and enforced by the courts. Common or co-ordinated policies are conducted in several areas. Undoubtedly there have been also influences of (b) on (a). In fact, the actual degree achieved over time in the economic and exchange rate integration of EU countries is likely to have affected the need to either defend or strengthen the achievements of institutional integration.

To what extent, however, can (and should) Latin America follow the footprint of Europe? Even if Latin America currently fulfils the OCA criteria to a lesser extent than Europe, this does not rule out the option of further deepening regional integration. A lesson might be that the process of regional integration will succeed in Latin America to the extent that realistic objectives are set in line with regional economic conditions and the prevailing level of political commitment? After all, 
the experience of the EU seems more in line with this line of reasoning. Not only is the EU not yet a fully-fledged OCA, but the EU process of integration has always had strong political roots, motivations and purposes. The political commitment has permitted the process to move forward through increasingly advanced institutional stages.

Admittedly more analysis is needed to explore the dynamic interaction between the process of institutional and economic integration, i.e., the fulfilment of certain OCA criteria (including, for instance, higher intra-regional trade, more synchronised business cycles, financial market integration and nominal convergence). Amongst others we would need to better understand the causalities between the two dimensions, and, if the analysis becomes dynamic and forwardlooking, what might allow to ignite, and sustain, a virtuous circle between institutional and economic integration at the regional level.

\section{Acknowledgements}

We would like to thank for their comments Pavlos Karadeloglou, Ciro Schioppa, Lutz Kilian, Georges Pineau, Julie McKay, Francesco Mazzaferro, Philippe Moutot, Stefania Scandizzo, and the the participants to presentations at the ECB, the Banco de España and a Joint Conference held in November 2002 by the International Economics and Finance Society (UK Chapter) with the Centre for International Capital Markets of the London Metropolitan University. Elvira Rosati assisted us with the data. We remain responsible for any error and omission. The views expressed are ours and do not necessarily reflect those of the ECB.

Received 11 February 2004, Accepted 12 August 2004

\section{References}

Alberola, E., A. Busián and F. de Lis. (2002), “The Quest for Nominal and Real Convergence Through Integration in Europe and Latin America," Banco de España, mimeo.

Anderton, R. and F. Skudelny. (2001), "Exchange Rate Volatility and Euro Area Imports", ECB Working Paper, 64, May.

Arize, A. (1996), "Real Exchange Variability and Trade Flows: the Experience of eight European Countries", International Review of Economics and Finance, 5(2), pp. 187-205. 
Arize, A., Osang, T. and Slottje, D.J. (1999), "Real Exchange Volatility in Latin America and its Impact on Foreign Trade", Unpublished paper.

Artis, M. and W. Zhang. (1998a), "Core and Periphery in EMU: A Cluster Analysis". EUI RSC Working Paper 98(37). Florence: European University Institute.

Artis, M. and W. Zhang. (1998b), "Membership of EMU: A Fuzzy Clustering Analysis of Alternative Criteria”. EUI RSC Working Paper 98(52). Florence: European University Institute.

Atkeson, A. and T. Bayoumi, (1993), "Do Private Capital Markets Insure Regional Risk? Evidence from the United States and Europe", Open Economies Review, 4, pp. 303324.

Balassa, B. (1961). The Theory of Economic Integration. Irwin, Homewood, Illinois.

Bayoumi, T. and B. Eichengreen. (1993), "Shocking Aspects of European Monetary Integration", in F. Torres and F. Giavazzi. (eds.) Adjustment and Growth in the European Monetary Union Cambridge University Press, Cambridge.

Bayoumi, T. and B. Eichengreen, (1997). "Ever Closer to Heaven? An Optimal Currency Index of European Countries". European Economic Review, 41, pp.760-70.

Baxter, M. and A.C. Stockman, (1989). "Business Cycles and the Exchange-Rate Regime". Journal of Monetary Economics, 27, pp. 377-400.

Ben-David, B., (1993). "Equalizing Exchange: Trade Liberalization and Income Equalization”. Quarterly Journal of Economics, 108, pp. 653-679.

Berg, A., Borensztein, E, and Mauro, P. (2000). "An Evaluation of Monetary Regime Options for Latin America". Paper presented at the seminar "Monetary Union: Theory, EMU Experience, and Prospects for Latin America", Vienna.

Canzoneri, M., J. Valles and J. Vinals, (1996). "Do Exchange Rates Move to Address International Macroeconomic Imbalances?”, CEPR Discussion Papers 1498. London, CEPR.

Caramazza, Ricci and Salgado, (2000), "Trade and Financial Contagion in Currency Crisess," International Monetary Fund, mimeo.

Chowdhury, A.R., (1993). "Does Exchange Rate Volatility Depress Trade Flows? Evidence from Error Correction Models". Review of Economics and Statistics, 75, pp. 700-706.

Christiano, L., M. Eichenbaum and C. Evans, (1999), "Monetary Policy Shocks: What Have We Learned and To What End?", in J. Taylor and M. Woodford (eds.), Handbook of Macroeconomics, North-Holland, Amsterdam.

Corden, W. M. (1972), "Monetary Integration, Essays in International Finance," International Finance Section 93, Department of Economics, Princeton University.

Cushman, D., (1988), "U.S. Bilateral Trade Flows and Exchange Rate Risk during the Floating Period", Journal of International Economics, 24, pp. 317-330.

DellAriccia, G., (1999). "Exchange rate Fluctuations and Trade Flows: Evidence from the European Union”, IMF Staff Paper, 46(3), pp. 315-334.

De Grauwe, P. and G. Verfaille, (1988). "Exchange Rate Variability, misalignment and the European Monetary System", in R.C. Marston ed., Misalignment of Exchange Rates: 
Effects on Trade and Industry. University of Chicago Press, pp. 77-103.

Dorrucci, E. (2002): "Integración regional y cooperación cambiaria en América Latina", CEMLA Boletín, 2, 2002, pp. 64-73.

Dorrucci, E., Firpo, S., Fratzscher, M. and Mongelli, F.P. (2002): "European Integration: What Lessons for Other Regions? The Case of Latin America", ECB Working Paper No. 185, October.

Dorrucci, E., Firpo, S., Fratzscher, M. and Mongelli, F.P. (2004): "The Link between Institutional and Economic Integration: Insights for Latin America from the European Experience," Open Economies Review Vol. 15 No.3 (July).

Eichengreen, B., (1990), "One Money for Europe? Lessons from The U. S. Currency Union," Economic Policy: a European Forum, 5(1), pp. 118-187, April.

Eichengreen, B., (1998). "Does Mercosur Need a Single Currency?”. NBER Working Paper 6821, Cambridge, MA.

European Central Bank, (1999), "Inflation Differentials in a Monetary Union," European Central Bank, Frankfurt Germany, Monthly Bulletin, October.

European Central Bank, (2001), The Monetary Policy of the ECB, European Central Bank, Frankfurt.

Emerson, M., D. Gros A. Italianer, J. Pisani-Ferry, H. Reichenbach, (1992), One Market, One Money, Oxford University Press, Oxford.

Everitt, B.S., (1993). Cluster Analysis, Edward Arnold $3^{\text {rd }}$ ed., London.

Flam, H. and P. Jansson, (2000), "EMU Effects on International Trade and Investment". Institute for International Economic Studies Seminar Paper, 683, Stockholm University.

Fleming, J. Marcus, (1971), “On Exchange Rate Unification,” The Economic Journal, 81, pp. 467-88.

Forbes and Rigobon, (2000), "Measuring Contagion: Conceptual and Empirical Issues," MIT-Sloan School of Management, mimeo.

Frankel, J. and A.K. Rose, (1997), "IS EMU more Justifiable Ex-post than Ex-ante?", European Economic Review, 41, pp. 753-60.

Frankel, J. and A.K. Rose, (1998), "The Endogeneity of the Optimum Currency Area Criteria”. Economic Journal, 108, pp. 1009-1025.

Frankel, J. and S. Wei, (1993), “Trade Blocs and Currency Blocs”. NBER Working Paper 4335, Cambridge, MA.

Fratianni, M. and A. Hauskrecht, (2002), “A Centralised Monetary Union for Mercosur: Lessons from EMU", paper presented at the Conference on "Euro and Dollarization: Forms of Monetary Union in Integrated Regions", Fordham University and CEPR, New York.

Fratzscher, M., (2000), “On Currency Crises and Contagion” Institute for International Economics Working Paper, Washington D.C.

García Herrero, A and J. Santillán, (2002), "Latin American Financial Development in Perspective," Banco de España, mimeo.

Gaspar, V. and F.P. Mongelli, (2001), "European Monetary Unification and the Single 
Market," forthcoming in the proceedings of the 2001 East-West Conference on Convergence held at the Bank of Austria in October 2001.

Gordon, A.D., (1999), Classification. $2^{\text {nd }}$ ed. Boca Raton, FL: CRC Press.

Hochreiter E., K. Schmidt-Hebbel and G. Winkler, (2002), "Monetary Union: European

Lessons, Latin American Prospects", paper presented at the Conference "Monetary Union: Theory, EMU experience, and prospects for Latin America" co-organised by the Oesterreichische Nationalbank on 15-16 April 2002.

Ingram, J.C., (1973), "The Case for the European Monetary Integration." Princeton University, Essays in International Finance, No. 98.

Issing, O., (1996), "Europe: Political Union Through Common Money?", The Institute of Economic Affairs.

Issing, O., (2001), "Economic and Monetary Union in Europe: political priority versus economic integration?" Paper for the Conference 2001 of the European Society for the History of Economic Thought, February.

Kaufman, L. and P.J. Rousseeuw, (1990), Finding Groups in Data. New York: John Wiley \& Sons.

Kenen, P.B., (1969), The Theory of Optimal Currency Areas: An Eclectic View, in R.A. Laird, S., (1997), "Mercosur: Objectives and Achievements". World Bank, Economic Notes 22, June.

McKinnon, R. I., (2001), “Optimum Currency Areas Revisited,” Stanford University, mimeo. Milesi-Ferretti, G.M., and Assaf Razin, (1996), "Current Account Sustainability.” Princeton Studies in International Finance, 81, Princeton University Press, Princeton, NT.

Mongelli, F.P., (2002), "“New” Views on the Optimum Currency Area Theory: What is EMU Telling Us?”, ECB Working Paper, 138, April.

Kenen, P. and D. Rodrik, (1986), "Measuring and analyzing the Effects of short-term Variability in Real Exchange Rates", Review of Economics and Statistics, 68, pp. 311-319.

Koray, F. and Lastrapes, (1989), "Real Exchange Volatility and US Bilateral Trade: a VAR approach", Review of Economics and Statistics, 71, pp. 708-712.

Masson P., (2000), "Multiple Equilibria, Contagion, and the Emerging Market Crises," IMF Working Paper 99/164.

McKinnon, R.I., (1963), "Optimum Currency Areas". American Economic Review, 53, pp. 717-25.

Mundell, R.A., (1961), “A Theory of Optimal Currency Areas”, American Economic Review, 51, pp. 105-46.

Mundell R.A., (1973), "Uncommon Arguments for Common Currencies", in H.G. Johnson and A.K. Swoboda, The Economics of Common Currencies, Allen and Unwin, pp. 114-32.

Obstfeld M. and K. Rogoff, (2000), "The Six Major Puzzles in International Macroeconomics: Is There a Common Cause?", NBER Working Paper, 7777, Cambridge, MA.

Padoa-Schioppa, T., (1982), "Capital Mobility: Why is the Treaty not Implemented", reprinted in "The Road to Monetary Union in Europe: the Emperor, the Kings and the 
Genies”, Oxford University Press, Oxford, 2000.

Padoa-Schioppa, T., (2000), "The European Union and the Nation State," The Hume Lecture 2000, Hume Occasional Paper no. 58.

Quah, D., (2000), "Discussion of A. Rose, One money, one market: the effect of common currencies on trade", Economic Policy, April.

Rose, A., (2000), "One money, one market: the effect of common currencies on trade", Economic Policy, April.

Rose, A., (2001), "Currency Unions and Trade: the Effect is Large", Economic Policy, October.

Scandizzo, S., (2002), "Options for Monetary Integration in the Andean Community", Corporación Andina de Fomento, mimeo.

Sims, C., (1980), "Macroeconomics and Reality", Econometrica, 48, pp. 1-48.

Summers, R. and A. Heston, (1988), "A New Set of International Comparisons of Real Product and Price Levels Estimates for 130 Countries, 1950-1985". Review of Income and Wealth, 34, pp. 1-25.

Tavlas, G. S., (1993), "The New Theory of Optimum Currency Areas", The World Economy, pp. 663-685.

Tavlas, G. S., (1994), "The Theory of Monetary Integration," Open Economies Review, 5(2), pp. 211-230.

Van Rijckeghem and Weder, (1999), "Sources of Contagion: Finance or Trade?", IMF Working Paper 99/146, October.

Werner Report, (1970), "Report to the Council and the Commission on the Realisation by Stages of Economic and Monetary Union in the Community," Supplement to Bulletin 11 1970, Luxembourg. 